is a tendency to gradually increase the bactericidal, lysozyme and phagocytic activity of blood serum under the influence of the enzyme used. The lysocyme activity of both experimental groups (II, III-experimental) increased by $6.7 \%$ compared with control. Indicators of bactericidal activity in her and III - experimental group were statistically more reliable $(P<0.05)$.

The obtained results lead to the conclusion that the enzyme preparation mainly raises the natural immune response of the organism, that is, it increases immunity.

It was established that the optimum rate of administration of the enzyme preparation "Cleared granulated" in the composition of fodder for chickens $0.4 \mathrm{~kg}$ per ton.

Keywords: enzymes, "Klerizym granular", lysozyme, blood, resistance, chickens.

\title{
REFERENCES
}

1. Bolotnykov I.A. Hematolohiya ptakhiv/I.A. Bolotnykov, YU.V. Solovyov. - L .. Nauka, 1980. - 164 s.

2. Voronin E.S. Imunolohiya / E.S. Voronin, A.M. Petrov, M.M. Sirykh, D.A. Devrishov. - M.: Kolos-Pres. - $2002 .-408$ s.

3. Ibatullin I.I. Hodivlya sil's'kohospodars'kykh tvaryn / I.I. Ibatullin, D.O. Mel'nychuk, H.O. Bohdanov ta in. // Vinnytsya: «Nova knyha». - 2007. - 616 s.

4. Karuns'kiy, O.Y. Fermentnyy preparat "Klerizym hranul'ovanyy" v hodivli remontnoho molodnyaku kurey-nesuchok [Tekst] / Karuns'kyy O.Y., Makaryns'ka A.V., Sevast'yanov O.V. // Zernovi produkty i kombikormy, 2017. -V. 17. - I. 1 (65). - R. 40-46.

5. Plokhyns'kyy N.A. Kerivnytstvo po biometriyi dlya zootekhnikiv / N.A. Plokhyns'kyy. - M .: Kolos, 1969. - 352s.

6. Fisinin V.I. Innovatsiyni metody borot'by zi stresamy v ptakhivnytstvi / V.I. Fisinin, T.T. Papazyan, P.F. Suray // Ptakhivnytstvo. - 2009.-N8.-S. 10-14.

Надійшла 15.03.2018. До друку 26.03.2018 Адреса для переписки: вул. Канатна, 112, м. Одеса, 65039

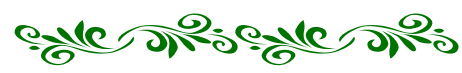

\section{ПЕРСПЕКТИВИ ВИКОРИСТАННЯ ГОРОХОВОЇ СОЛОМИ ПРИ ВИРОБНИЦТВІ КОМБІКОРМОВОЇ ПРОДУКЦІЇ}

Анотація

В роботі наведено аналіз ринку гороху у світі та Україні, показано тенденцію зростання обсягів вирощування, щцо зумовлене зростанням попиту на харчовий і кормовий білок. Проаналізовано поживну цінність, переваги використання зерна гороху у харчовій і комбікормовій промисловості.

Показано, щео при вирощуванні гороху в Украӥні отримується значна кількість вторинного ресурсу - соломи, яка не використовується, щчо недоцільно як з економічної так $і$ з екологічної точок зору. Це також суперечить актуальним світовим тенденціям сьогодення шеодо максимально ефективного використання усіх доступних видів харчової і кормовоі сировини для забезпечення продовольчої безпеки населення, зменшення негативного впливу на навколишнє середовище. Показано, щь використання горохової соломи у комбікормовій промисловості дозволить повернути значний обсяг природного ресурсу у ланцюг створення продуктів для людей, крім того, сприятиме збільшенню виробництва тваринного білка.

Проаналізовано хімічний склад горохової соломи, встановлено значно більщу поживну цінність, у порівнянні з соломою злакових. Проаналізовано світовий досвід застосування горохової соломи в раиіонах сільськогосподарських тварин ma птичі.

Визначено фізичні властивості борошна з горохової соломи, встановлено щь ї̈ можна віднести до важкосипких видів сировини, а отже потребує традиційних прийомів для покращення транспортування, випуску з оперативних ємностей. Визначено гранулометричний склад борошна з горохової соломи, встановлено дочільність застосування подрібнення у 2 етапи із проміжним виділеням дрібної фракиії і доподрібненням крупної. Це дозволить зменшити енерговитрати на подрібнення, отримати більш вирівняну за крупністю суміш та уникнути переподрібнення окремих частинок.

Експериментами in vivo визначено: вплив відсотку введення борошна з горохової соломи до складу раціонів лабораторних тварин на приріст маси лабораторних тварин, встановлено максимальний ефект при введенні 3 \%; вплив крупності подрібнення горохової соломи на ефективність згодовування, встановлено щчо фракиія борошна з розміром часток від 0,56 до 0,8 мм є більш оптимальною для годівлі, оскільки сприяє збільшенню приростів маси тіла у 2,2 рази у порівнянні з контролем, в той час для фракції з розміром частинок менше 0,56 мм цей показник становить 1,5 рази.

Експериментами іп vivo визначено лікувально-профілактичні властивості борошна з горохової соломи, здатність нівелювати негативні ефекти застосування антибіотика, ліквідувати запалення у слизовій оболонці тонкої кишки, має позитивний вплив на неспецифічний імунітет, пребіотичні властивості.

Ключові слова: горохова солома, комбікорм, дисбіоз, пребіотик. 
Вступ

Стрімке зростання чисельності населення планети значно загострило проблему забезпечення людей тваринним білком. На даний час дефіцит тваринного білка становить 25 \% від потреби. Враховуючи вищевказане, Генеральна Асамблея ООН оголосила 2016 рік «Міжнародним роком зернобобових» для збільшення їх виробництва і товарообігу, заохочення нових і раціональних методів використання впродовж всього харчового ланцюга [1].

Зернобобові культури відіграють велику роль в харчуванні людини і годівлі сільськогосподарських тварин, поліпшенні родючості грунтів, зменшенні частки застосування синтетичних добрив, не мають аналогів по збору жиру та білка (з високим вмістом лізину) з одиниці площі, сприяють грунтовій біорізноманітності, створюють умови для мікроорганізмів і бактерій, мають низький рівень накопичення токсичних речовин з грунту [2].

Горох - одна з найдавніших культур. В археологічних розкопках насіння гороху вперше були знайдені в шарах, що відносяться до неолітичної періоду кам'яного віку. Горох має велике харчове значення і вирощується, головним чином, як продовольча культура. Насіння гороху є джерелом рослинного білка, відрізняються розварюємістю і високими смаковими якостями. Разом із продовольчою значенням, горох використають на кормові цілі, і він набуває більшої популярності як концентрат для тварин. Вміст антипоживних речовин (інгібіторів протеаз) у горосі значно нижче в порівнянні з іншими зернобобовими культурами, їх рівень знижується із застосуванням температурної обробки [3,4]. Встановлено високий вміст білка, метаболізуємої енергії, біодоступність амінокислот у зерні гороху [5]. Встановлено позитивний вплив зерна гороху в раціонах телят на органолептичні показники м'яса ніжність, соковитість [6]. Для уникнення ацидозу крохмаль у раціонах для ВРХ повинен мати низьку швидкість деградації. Встановлено що швидкість деградації крохмалю гороху (4-6 $\%$ / год), в той час як для ячменю цей показник (21-34 $\%$ / год). Крохмаль пшениці має найбільшу швидкість перетравлення серед усіх зернових. Горох можна включати у кількості до 25\% у концерн- трати для дійних корів $[7,8]$.

Світова посівна площа гороху близько 8 млн га. Найбільшими світовими виробниками гороху у 2017 році були Канада, країни Свросоюзу, Росія, Китай, Україна із часткою світового обсягу збору відповідно, \%: 28; 21; 21; 8; 8. Валовий збір гороху в Україні за останні роки значно зріс, якщо у 2012/2013p. обсяг становив 349 тис.т, то у 2016/2017p цей показник був 755 тис. т. завдяки збільшенню посівних площ. Вказана тенденція характерна для країн Свросоюзу та Росії. Передумовами зростання є збільшення світового споживання, нові тренди здорового харчування 3 використанням бобових, необхідність відновлення сівозміни після перенасиченості посівів олійних культур [9].

При вирощуванні гороху отримують солому, кількість якої залежить від сортових особливостей, кліматичних, агротехнічних умов, але в середньому рівна кількості отриманого зерна. Враховуючи обсяг вирощування, в 2017 р отримано близько 800 тис. т. вторинного ресурсу, який не знайшов використання, що недоцільно як 3 економічної так і 3 екологічної точок зору. Це також суперечить актуальним світовим тенденціям сьогодення щодо максимально ефективного використання усіх доступних видів харчової і кормової сировини для забезпечення продовольчої безпеки населення, зменшення негативного впливу на навколишнє середовище.

Таким чином, актуальною проблемою є пошук раціональних способів повернення горохової соломи у ланцюг створення продуктів для людей i найкращим варіантом може бути використання у комбікормовій промисловості, оскільки сприятиме збільшенню виробництва тваринного білка.

Враховуючи вищевказане, метою досліджень було обгрунтування доцільності використання горохової соломи у комбікормовому виробництві.

Для досягнення вказаної мети були поставлені такі задачі:

- $\quad$ провести аналіз ринку вирощування гороху в світі та в Україні;

- визначити поживну цінність горохової соломи;

- визначити фізичні властивості борошна з горохової соломи;

- визначити біологічну оцінку ефективності використання горохової соломи в годівлі сільськогосподарських тварин.

\section{Матеріали і методи досліджень}

Борошно з горохової соломи отримували на лабораторному ножовому подрібнювачі з наступним поділом на фракції. Фізичні властивості отриманого борошна визначали згідно з методиками [10]. Біологічну оцінку кормової цінності горохової соломи визначали на лабораторних тваринах (щурі лінії Вicтар). В ході експерименту визначали приріст живої

Таблиця 1 - Хімічний склад кормових засобів, \%

\begin{tabular}{|c|c|c|c|c|c|c|c|c|c|c|}
\hline "Найменування & $\begin{array}{c}\text { Суха } \\
\text { речовина }\end{array}$ & $\begin{array}{l}\text { Сира } \\
\text { зола }\end{array}$ & $\begin{array}{c}\text { Сирий } \\
\text { протеїн }\end{array}$ & $\begin{array}{c}\text { Сира } \\
\text { клітковина }\end{array}$ & $\begin{array}{l}\text { Сирий } \\
\text { жир }\end{array}$ & NDF & $\mathrm{ADF}$ & ADL & NDIN & ADIN \\
\hline $\begin{array}{l}\text { Солома } \\
\text { пшенична [10] }\end{array}$ & 92,6 & 6,9 & 2,6 & 48,5 & 0,8 & 83,4 & 56,3 & 8,0 & 0,15 & 0,16 \\
\hline $\begin{array}{l}\text { Солома } \\
\text { горохова }[10,12]\end{array}$ & 91,6 & 8,7 & 9,1 & 41,3 & 1,7 & 54,5 & 48 & 9,0 & 0,36 & 0,15 \\
\hline $\begin{array}{l}\text { Солома } \\
\text { горохова [11] }\end{array}$ & 92,1 & 4,3 & 5,3 & 33,0 & 1,7 & - & - & - & - & - \\
\hline
\end{tabular}


маси. Для визначення лікувально-профілактичних властивостей горохової соломи відтворювали у лабораторних тварин експериментальний дисбіоз з допомогою антибіотика лінкоміцину [11]. В кінці експерименту щурів умертвляли під тіопентаноловим наркозом (20 мг/кг), в них виділяли слизові оболонки тонкої та товстої кишок, частину печінки, сироватку крові. В гомогенаті тканин визначали активність протеолітичного ферменту еластази (маркер запалення і деструкції тканин), активність лізоциму (маркер неспецифічного імунітету, дисбіозу) [12].

\section{Результати і обговорення}

На першому етапі було проаналізовано поживну цінність горохової соломи (табл. 1). Дослідженнями проведеними у різних країнах, встановлено, що у порівнянні з пшеничною соломою, горохова містить у $2-3,5$ рази вище протеїну; в 2 рази більше сирого жиру; вміст клітковини менше в 1,2-1,5 рази, що свідчить про значно вищу ії поживну цінність.

Вміст нейтрально-детергентної клітковини менше на 36\%, кислотно- детергентної клітковини менше на 14,7\%. MalushiI (2017) визначено ступінь засвоюваності протеїну ферментативним методом та методом Tilley та Terry, встановлено що для соломи зернових злакових показник становить 29,7 $\pm 3,3$; $47,4 \pm 2,9 \%$ а для горохової відповідно 42,7士6,1; $58,8 \pm 5,0 \%$ [13].

Вміст макроелементів $\mathrm{Ca}, \mathrm{P}, \mathrm{Mg}, \mathrm{Na}, \mathrm{K}$ у гороховій соломі становить відповідно: 1,$31 ; 0,24 ; 0,39$; 0,$01 ; 1,40 \%$ [8]. Високий вміст кальцію у гороховій соломі встановлено і Лазаревичем А.М. (2016) - 1,6 $\%$, в той час як аналогічні показники у соломі злакових коливаються в межах 0,5-0,9\%. В 1 кг соломи горохової 2,4 г лізину, 4,0 г метіоніну+цистину [14].

Враховуючи вказане, а також необхідність розширення кормової бази комбікормової промисловості через загострення дефіциту харчової і кормової сировини в усьому світі, в останній час проводяться дослідження по визначенню зоотехнічної ефективності використання горохової соломи в багатьох країнах. Багатьма авторами підтверджується доцільність використання горохової соломи у годівлі жуйних тварин, що забезпечує рентабельність галузі $[6,15]$. Забезпечити високу продуктивність ВРХ молочного напряму неможливо без забезпечення ацетатного типу бродіння у рубці, оскільки оцтова кислота, що утворюється при цьому є попередником молочного жиру. Досягти вказаного можна застосуванням грубих кормів, зокрема, горохової соломи [7]. Gregorini (2016) проведені дослідження по визначенню комбінації різних кормових засобів, включаючи горохову солому для зменшення викидів метану та екскреції азоту що не тільки недоцільно з точки зору втрати поживних речовин у тваринництві, а і екологічного забруднення відходами через вилужування земель, утворення оксидів азоту [16]. Відходи гороху (стручки, стебла) можна включати у кількості до $20 \%$ у ра-

\begin{tabular}{|c|c|c|c|c|}
\hline $\begin{array}{c}\text { Масова } \\
\text { частка } \\
\text { вологи, } \\
\%\end{array}$ & $\begin{array}{c}\text { Кут приро- } \\
\text { дного ухи- } \\
\text { лу, град. }\end{array}$ & 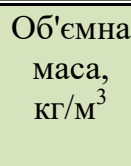 & $\begin{array}{c}\text { Сипкість, } \\
\mathrm{cm}^{3} / \mathrm{c}\end{array}$ & $\begin{array}{c}\text { Модуль } \\
\text { крупності, } \\
\text { мм }\end{array}$ \\
\hline 9,1 & 57 & 132 & 10,1 & 0,89 \\
\hline 12,1 & 55 & 460 & 11,1 & 1,25 \\
\hline
\end{tabular}

ціони для бройлерів без погіршення росту та ефективності корму [8].

На наступному етапі досліджень було визначено фізичні властивості виготовленого в лабораторних умовах борошна з горохової соломи (табл. 2).

Як видно 3 отриманих даних, за своїми фізичними властивостями борошно з горохової соломи наближається до рибного борошна, практично подібні кути природного ухилу, низька сипкість. Борошно з горохової соломи можна віднести до важкосипких видів сировини, а отже потребуватиме загальноприйнятих прийомів для покращення транспортування, випуску 3 оперативних ємностей. Об'ємна маса у борошна 3 горохової соломи у 3,5 рази менше, ніж у рибного борошна та наближається до лузги зернових, соломи злакових.

Визначено гранулометричний склад борошна 3 горохової соломи (рис. 1). Встановлено, що переважну частину суміші (близько 65 \%) становить фракція розміром $1 \pm 0,3$ мм. Значний вміст фракції розміром 0,25 мм - $20 \%$, що свідчить про переподрібнення окремих частинок горохової соломи, в той час як до $15 \%$ фракції з розміром більше 1,5 мм. Що, очевидно, зумовлене різним хімічним складом та структурою складових соломи (листя, стебла, стручки) які мають різні фізичні властивості, пластичність. Очевидною є необхідність застосування подрібнення у 2 етапи із проміжним виділеням дрібної фракції і доподрібненням крупної. Це дозволить зменшити енерговитрати на подрібнення, отримати більш вирівняну за крупністю суміш та уникнути пере подрібнення окремих частинок.

На наступному етапі досліджень було проведено дослідження по визначенню кормової цінності горохової соломи. У першій серії досліджень визначали вплив відсотку введення борошна з горохової

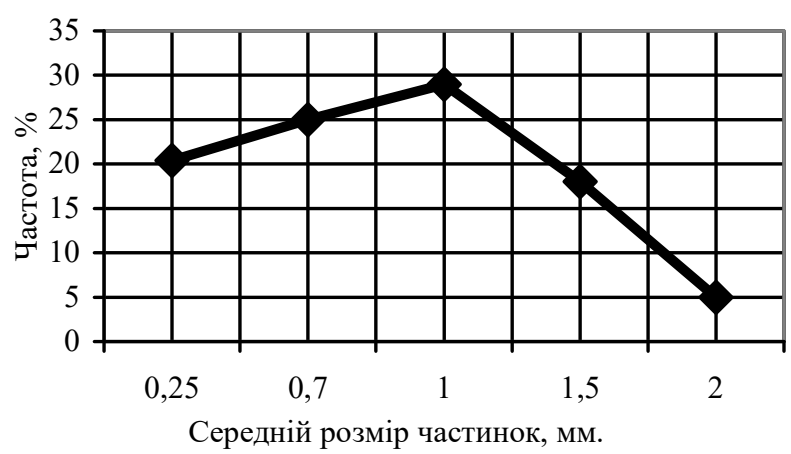

Рис. 1 - Гранулометричний склад борошна з горохової соломи प 


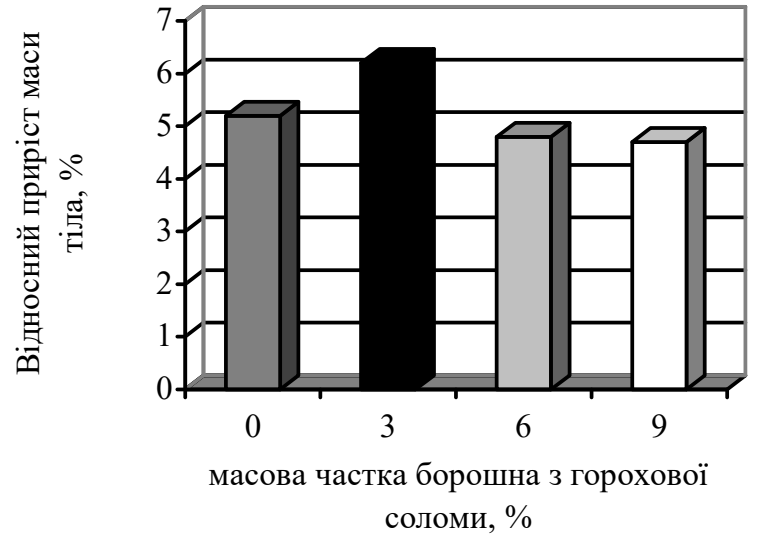

Рис. 2 - Відносний приріст маси тіла лабораторних тварин за 1 добу

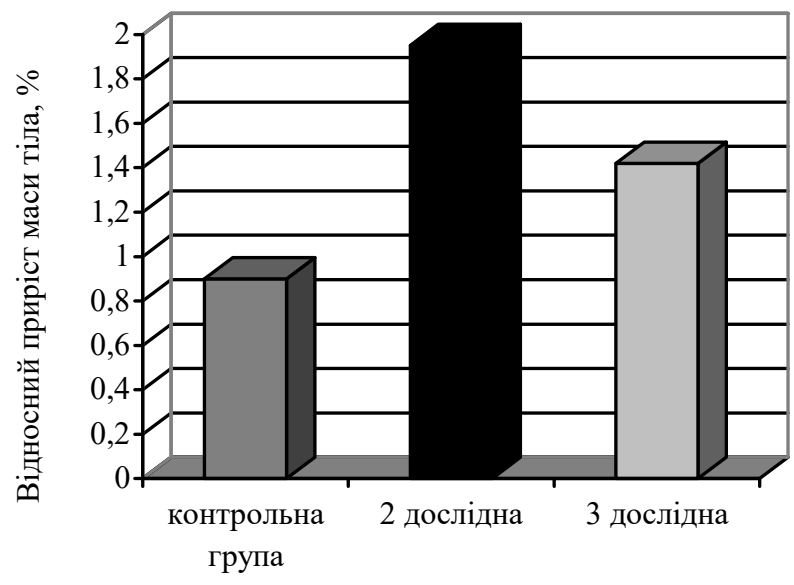

Рис. 3 - Відносний приріст маси тіла лабораторних тварин за 1 добу

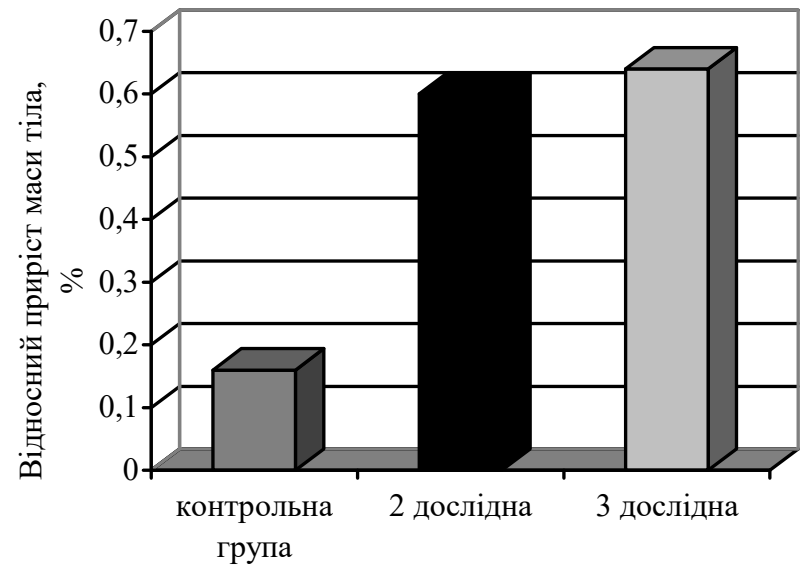

Рис. 4 - Відносний приріст маси тіла лабораторних тварин за 1 добу

соломи до складу раціонів лабораторних тварин. Було сформовано 4 групи лабораторних тварин (самці щурів віком 3 місяці) 1- контрольна, 2, 3, 4 дослідні які відрізнялись заміною частини зерна пшениці на борошно з горохової соломи відповідно по групах на 3, 6, 9 \%. Визначали відносний приріст живої маси тіла за 7 днів. Результати наведені на рис. 2. Як видно 3 отриманих даних, прирости маси тіла у 2 групі бі- льші за контроль на 20 \%, що свідчить не тільки про можливість заміни частини зерна, а і доцільність, 3 точки зору позитивного впливу на організм. Проте, при збільшенні частки введення до 6, 9 відсотків помітне зменшення приростів маси тіла на 8,2 \% у порівнянні $з$ контролем і на 21\% у порівнянні з 2-ю дослідною групою.

У наступній серії досліджень було визначено вплив крупності борошна $з$ горохової соломи на прирости мас лабораторних тварин. Було сформовано 3 групи лабораторних тварин (самці щурів віком 1,5 місяці) 1- контрольна, 2, 3 дослідні які відрізнялись заміною 5 \% зерна пшениці у раціонні на борошно 3 горохової соломи різної крупності 2 дослідна - фракція прохід сита розміром 0,8 мм та схід сита розміром 0,56 мм 3 дослідна - прохід сита розміром 0,56 мм. Результати наведені на рис. 3. Як видно з отриманих даних, у 2 дослідній групі прирости маси тіла найбільші і у 2,2 рази перевищують аналогічний показник у контролі. Значно менший ефект у порівнянні 3 контролем виявлено у 3 групі, збільшення становить 1,5 рази. Що можна пояснити появою різноманітних порушень травлення, залипання часточок корму на мікроворсинках епітелію, як наслідок зменшення всмоктувальної поверхні, поява запалень. Очевидною $є$ необхідність надання мілкодисперсній фракції більш фізіологічно придатної структури, враховуючи що кількість такої фракції при подрібненні, як зазначалось раніше, істотна.

У наступній серії досліджень визначали здатність горохової соломи знизити негативні наслідки застосування антибіотика. Було сформовано 3 групи лабораторних тварин (самці щурів віком 1,5 місяці) 1 - контрольна (інтактна), яка отримувала зерно пшениці 2 дослідна відрізнялись введенням лінкоміцину (70 мг/кг), 3 дослідна відрізнялась від 2-ї додатковим введенням замість $10 \%$ пшениці борошна 3 горохової соломи (прохід сита розміром 0,8 мм). Результати наведені на рис. 4.

Як видно 3 отриманих даних, лінкоміцин значно підвищує приріст маси лабораторних тварин у 2-й дослідній групі, що узгоджується із відомим ростостимулюючим ефектом антибіотику. Введення борошна 3 горохової соломи дещо покращує приріст маси тіла у 3-й дослідній групі, проте неістотно у порівнянні з 2-ю групою. На наступному етапі досліджень щурів умертвляли під тіопентаноловим наркозом (20 мг/кг), в них виділяли слизові оболонки тонкої та товстої кишок, частину печінки, сироватку крові. В гомогенаті тканин визначали активність протеолітичного ферменту еластази (маркер запалення i деструкції тканин) [17], активність лізоциму (маркер неспецифічного імунітету, дисбіозу) [18] (табл. 3).

Встановлено, що введення лінкоміцину у 2-у дослідну групу призводить до появи дисбіотичного стану, зниження неспецифічного імунітету про що свідчить зниження в 1,4 рази рівня лізоциму. Визначено маркери запалення і дистрофії еластазу, МДА, встановлено, що введення лінкоміцину в 1,2 рази підвищує рівень еластази та в 1,3 рази МДА у порівнянні з інтактною 1 групою, що свідчить про появу патологічних станів. 
Таблиця 3 - Біохімічні показники слизової оболонки кищки

\begin{tabular}{||c||c||c||c||c||c||}
\hline \multicolumn{1}{|c||}{ Групи } & \multicolumn{3}{|c||}{ Показники } \\
\cline { 2 - 6 } & $\begin{array}{c}\text { Уреаза, } \\
\text { мккат/кг }\end{array}$ & $\begin{array}{c}\text { Лізоцим, } \\
\text { од/кг }\end{array}$ & $\begin{array}{c}\text { Каталаза, } \\
\text { мккат/кг }\end{array}$ & $\begin{array}{c}\text { МДА, } \\
\text { ммоль/кг }\end{array}$ & $\begin{array}{c}\text { Еластаза, } \\
\text { мкат/кг }\end{array}$ \\
\hline \hline Контрольна (інтактна) & $0,38 \pm 0,31$ & $275 \pm 35$ & $4,05 \pm 0,5$ & $6,51 \pm 0,51$ & $1,41 \pm 0,1$ \\
\hline \hline дослідна (з введенням лінкоміцину) & $1,92 \pm 0,75$ & $191 \pm 0,32$ & $3,31 \pm 0,3$ & $7,74 \pm 0,32$ & $1,63 \pm 0,5$ \\
\hline \hline $\begin{array}{l}3 \text { дослідна (з введенням лінкоміцину і } \\
10 \% \text { борошна з горохової соломи) }\end{array}$ & $4,87 \pm 1,87$ & $214 \pm 0,43$ & $3,66 \pm 0,19$ & $3,85 \pm 0,48$ & $1,08 \pm 0,05$ \\
\hline \hline
\end{tabular}

Як видно з таблиці 3, введення горохової соломи дозволяє нівелювати негативні ефекти антибіотика, ліквідувати запалення у слизовій оболонці тонкої кишки, про що свідчить зменшення рівня маркерів запалень еластази, МДА до рівня інтактної групи i нижче. Встановлено позитивний вплив на неспецифічний імунітет, пребіотичні властивості горохової соломи, зокрема у 3 дослідній групі зріс вміст лізоциму.

Таким чином, незважаючи на значні збільшення приростів маси тіла у лабораторних тварин 2 групи (із введенням лінкоміцину), біохімічні дослідження дозволили встановити появу запалень, дисбіозу, патологічного стану, який в подальшому зумовлює порушення функції травлення, ініціює низку захворювань. Незважаючи на відсутність істотної різниці у приростах маси тіла дослідних груп 2 і 3, біохімічні дослідження дозволили виявити істотний вплив введення борошна з горохової соломи на стан здоров'я тварин 3 групи. Таким чином, відсутність очевидної різниці у приростах маси тіла зумовлена не відсутністю негативного ефекту антибіотику і лікувально-профілактичної дії борошна 3 горохової соломи, а фізіологічними особливостями формування патологічних станів та часом прояву симптомів порушень.На основі проведеної роботи можна зробити наступні висновки.

1.Використання горохової соломи при виробництві комбікормової продукції дозволить поверну- ти у ланцюг створення харчових продуктів значний обсяг вторинного ресурсу.

2.Горохова солома має найбільшу поживну цінність у порівнянні з іншими видами соломи.

3.Встановлено, що за фізичними властивостями борошно з горохової соломи може використовуватись при виробництві комбікормової продукції, відноситься до важкосипких видів сировини, тому потребує традиційних підходів до такої сировини у технологічному процесі виробництва.

4.Доцільним є застосування 2-етапного здрібнення горохової соломи, що дозволить зменшити енерговитрати, сприятиме більш вирівняному складу суміші, зменшиться частка переподрібненої фракції.

5. Встановлено, що заміна $3 \%$ пшениці на борошно з горохової соломи не тільки не погіршує ефективність комбікорму, а і навпаки, збільшує прирости маси тіла лабораторних тварин.

6.Встановлено, що фракція борошна з розміром часток від 0,56 до 0,8 мм $є$ більш оптимальною для годівлі, оскільки сприяє збільшенню приростів маси тіла у 2,2 рази у порівнянні з контролем, в той час для фракції з розміром частинок менше 0,56 мм цей показник становить 1,5 рази.

7.Встановлено, що введення горохової соломи до складу раціону лабораторних тварин дозволяе нівелювати негативні ефекти антибіотика, ліквідувати запалення у слизовій оболонці тонкої кишки, має позитивний вплив на неспецифічний імунітет, пребіотичні властивості.

\section{ЛIТЕРАТУРА}

1. От лимской фасоли до голубиного гороха: ООН запускает Международный год зернобобовых. Електронний реcypc. - Pежим docmyny http://www.fao.org/news/story/ru/item/343653/icode/

2. Січкар, В.I. Бобова для сівозмін Півдня / Farmer. - №10(94). - 2017. - C. 68-72.

3. Возиян, В.И. Питательная ценность сортов сои, гороха, фасоли и содержание в них антипитательных веществ / В.И. Возиян, М.Г. Таран, М.Д. Якобуиа, Л.П. Авадэний «Зернобобовые и крупяные культурыз». - №1(5) - 2013. C.26-29

4. Косолапов В. М. Роль кормових зернобобових культур в укреплении кормовой базы животноводства / В. М. Косолапов И. А. Трофимов «Зернобобовые и крупяные культуры», № 1, 2012 г С 98-101

5. E. Koivunen, Digestibility and energy value of pea (Pisum sativum L.), faba bean (Vicia faba L.) and blue lupin (narrowleaf) (Lupinus angustifolius) seeds in broilers / E. Koivunen, K. Partanen, S. Perttilä, S. Palander, P. Tuunainen, J. Valaja // Animal Feed Science and Technology, Volume 218, 2016, Pages 120-127

6. Field Pea Grain and Forage for Beef Cattle. Електронний ресурс. - Режим доступу https://www.ag.ndsu.edu/publications/livestock/field-pea-grain-and-forage-for-beef-cattlelas1301.pdf

7. Acidosis in cattle a revive / F.N. Owens, D.S. Secrit, W.J. Hill, D.R. Gill // Journal of Animal Science. - 1998. - V 1. - P 275-286.

8. Waste_to_worth_vegetable_wastes_as_animal_feed. Електронний ресурс. - Режим доступу https://www.researchgate.net/profile/Mohinder_Bakshi/publication/306395604_Waste_to_worth_vegetable_wastes_as_ani mal_feed/links/57bcb21908aedf5f75eaa45d/Waste-to-worth-vegetable-wastes-as-animal-feed.pdf $\bar{f}$

9. Страны Причерноморья вытесняют «старожилов» с рынка бобовых культур. Електронний ресурс. - Режим docmyny http://www.ukragroconsult.com/news/strany-prichernomorya-vytesnyayut-starozhilov-s-rynka-bobovyh-kultur

10. Методичні вказівки до виконання лабораторних робіт з курсу «Науково-технічний прогрес у зернопереробній галузі» (комбікормова галузь). - Ч.1. - Одеса. -47 c. 
11. Левицький А. П. Деклараційний патент на корисну модель № 31012. Спосіб моделювання дисбіозу (дисбактеріозу) / А. П. Левицький, І. О. Селіванська, Ю. В. Цісельський [та ін.] - № и 200711609; заявл. 22.10.2007; опубл. 25.03.2008. Бюл. № 6.

12. Левицький А.П. Біологічний метод визначення пребіотичних властивостей продуктів функиіонального призначення / А.П. Левицький, В.Т. Гулавський, І.О. Селіванська // Наукові праці ОНАХТ. - 2012. - вип. 42.m.1. - C. $194-197$.

13. Nertila Malushi Determination of chemical content and dru matter digestibility of some under-utilized feeds in ruminant feeding through two in vitro metods / Nertila Malushi, Lumturi Papa, Margarida Mai, Hugo Oliver // Animal Science. Vol. $L X, 2017 .-$ P.91-96.

14. Лазаревич А.Н. Солома в рационах сельскохозяйственных животных: рекомендации / А.Н. Лазаревич, А.П. Леснов; ФГБНУ Красноярский НИИЖ. - Красноярск, 2016. - 90 с.

15. Jane Wamatu Nutritive value of field pea (Pisum sativum L.) straw as influenced by variety, season, botanical fractions and urea pretreatment / Jane Wamatu, Ashraf Alkhtib, Dawit Abate, Seid Ahmed Kemal, Barbara Rischkowsky // Animal Feed Science and Technology. - Volume 225. - 2017. - P. 54-61. ISSN 0377-8401.

16. Pablo Gregorini Screening for diets that reduce urinary nitrogen excretion and methane emissions while maintaining or increasing production by dairy cows / Pablo Gregorini, Pierre C. Beukes, Dawn Dalley, Alvaro J. Romera // Science of the Total Environment. - 2016. P.- 32-41.

17. Биохимические маркеры воспаления тканей ротовой полости: метод. рекомендации / А.П. Левицкий, О.В. Деньга, O.А. Макаренко [и др.]. - Одесса, 2010. - 16 c.

18. Ферментативный метод определения дисбиоза полости рта для скрининга про- и пребиотиков: метод. рекомендаичи / А. П. Левиикий, О. А. Макаренко, И.А. Селиванская [и др.]. - К.: ГФЦ, 2007. - 26 с.

A.P. LEVITSKY ${ }^{1,2}$, Dr. biology Sciences, professor, A.P. LAPINSKAYA ${ }^{1}$, PhD.Sc Science, Ass. professor, V.I. SICHKAR ${ }^{3}$, Dr. biology Sciences, professor, head of scientific and technical department, L.M. MUDRIK ${ }^{2}$, Junior Research Fellow , M.E. NIKOLENKO ${ }^{1}$, student ${ }^{1}$ Odessa National Academy of Food Technologies, Odessa

${ }^{2}$ GA "Institute of Dentistry and Maxillofacial Surgery of NAMS of Ukraine"

${ }^{3}$ Odesan State Agricultural Research Station of NAAS of Ukraine

\title{
PROSPECTS FOR THE USE OF PEA STRAW IN THE PRODUCTION OF FEED PRODUCTS
}

\begin{abstract}
The analysis of the peas market in the world and Ukraine is presented, and the tendency of growth in growing volumes, which is conditioned by the growth of demand for food and feed protein, is shown. The nutritional value, advantages of using peas in the food and feed industry are analyzed.

It is shown that in growing peas in Ukraine there is a significant amount of secondary resource - straw that is not used, which is inappropriate both from the economic point of view and from the ecological point of view. It also contradicts the current world trends of today in relation to the most effective use of all available types of food and feed for ensuring the food security of the population, reducing the negative impact on the environment.

It has been shown that the use of pea straw in the feed industry will allow the return of a significant amount of natural resources to the human food chain and, moreover, will increase the production of animal protein.

The chemical composition of pea straw has been analyzed, and a much higher nutritional value is established, in comparison with straw of cereals. The world experience in using peas in straw in farm animals and poultry has been analyzed.

The physical properties of pea straw flour have been determined, it is established that it can be attributed to hard-core types of raw materials, and therefore requires traditional methods for improving transportation, release from operational capacities. The granulometric composition of flour from peanut straw has been determined, the expediency of application of crushing in 2 stages with the intermediate allocation of fine fraction and till the crushing of the large one is established. This will reduce the energy costs of grinding, obtain a more even-coagulating mixture and avoid crushing of individual particles.

In vivo experiments were determined: influence of the percentage of the input of pea straw flour from ratitudes of laboratory animals on the growth of the mass of laboratory animals, the maximum effect was set at the introduction of 3\%; the effect of grinder size grinding on the efficiency of feeding, it was established that the fraction of flour with a particle size of 0.56 to $0.8 \mathrm{~mm}$ is more optimal for feeding, since it contributes to an increase in body weight gain by 2.2 times compared with control, at that time for a fraction with a particle size of less than $0.56 \mathrm{~mm}$, this figure is 1.5 times.

Experiments in vivo determine the therapeutic and prophylactic properties of peanut flour, the ability to neutralize the negative effects of antibiotics, eliminate inflammation in the mucous membrane of the small intestine, has a positive effect on nonspecific immunity, prebiotic properties.
\end{abstract}

Key words: peas straw, feed, disbiosis, prebiotic.

\section{REFERENCES}

1. Ot limskoy fasoli do golubinogo goroha: OON zapuskaet Mezhdunarodnyiy god zernobobovyih. Elektronniy resurs. Rezhim dostupu http://www.fao.org/news/story/ru/item/343653/icode/

2. Sichkar, V.I. Bobova dlia sivozmin Pivdnia / Farmer. - №10(94). - 2017. - S. 68-72. 
3. Voziyan, V.I. Pitatelnaya tsennost sortov soi, goroha, fasoli i soderzhanie v nih antipitatelnyih veschestv / V.I. Voziyan, M.G. Taran, M.D. Yakobutsa, L.P. Avadeniy «Zernobobovyie i krupyanyie kulturyi». - \#1(5) - 2013. - S.26-29

4. Kosolapov V. M. Rol kormovih zernobobovih kultur v ukreplenii kormovoy bazyi zhivotnovodstva / V. M. Kosolapov I. A. Trofimov «Zernobobovyie i krupyanyie kulturyi», \# 1, $2012 \mathrm{~g}$ S 98-101

5. E. Koivunen, Digestibility and energy value of pea (Pisum sativum L.), faba bean (Vicia faba L.) and blue lupin (narrowleaf) (Lupinus angustifolius) seeds in broilers / E. Koivunen, K. Partanen, S. Perttilä, S. Palander, P. Tuunainen, J. Valaja // Animal Feed Science and Technology, Volume 218, 2016, Pages 120-127

6. Field Pea Grain and Forage for Beef Cattle. Електронний ресурс. - Режим доступу https://www.ag.ndsu.edu/publications/livestock/field-pea-grain-and-forage-for-beef-cattlelas1301.pdf

7. Acidosis in cattle a revive / F.N. Owens, D.S. Secrit, W.J. Hill, D.R. Gill // Journal of Animal Science. - 1998. - V 1. - P 275-286.

8. Waste_to_worth_vegetable_wastes_as_animal_feed. Електронний pecypc. - Режим доступу https://www.researchgate.net/profile/Mohinder_Bakshi/publication/306395604_Waste_to_worth_vegetable_wastes_as_ani mal_feed/links/57bcb21908aedf5f75eaa $45 d /$ Waste-to-worth-vegetable-wastes-as-animal-feed.pdf

9. Stranyi Prichernomorya vyitesnyayut «starozhilov»s ryinka bobovyih kultur. Elektronniy resurs. - Rezhim dostupu http://www.ukragroconsult.com/news/strany-prichernomorya-vytesnyayut-starozhilov-s-rynka-bobovyh-kultur

10. Metodychni vkazivky do vykonannia laboratornykh robit z kursu «Naukovo-tekhnichnyi prohres u zernopererobnii haluzi» (kombikormova haluz). - Ch.1. - Odesa. - 47 s.

11. Levytskyi A. P. Deklaratsiinyi patent na korysnu model № 31012. Sposib modeliuvannia dysbiozu (dysbakteriozu) / A. P. Levytskyi, I. O. Selivanska, Yu. V. Tsiselskyi [ta in.] - № u 200711609; zaiavl. 22.10.2007; opubl. 25.03.2008. Biul. № 6.

12. Levytskyi A.P. Biolohichnyi metod vyznachennia prebiotychnykh vlastyvostei produktiv funktsionalnoho pryznachennia $/$ A.P. Levytskyi, V.T. Hulavskyi, I.O. Selivanska // Naukovi pratsi ONAKhT. - 2012. - vyp. 42.t.1. - S. 194-197.

13. Nertila Malushi Determination of chemical content and dru matter digestibility of some under-utilized feeds in ruminant feeding through two in vitro metods / Nertila Malushi, Lumturi Papa , Margarida Mai, Hugo Oliver // Animal Science. Vol. $L X, 2017$. - P.91-96.

14. Lazarevich A.N. Soloma v ratsionah selskohozyaystvennyih zhivotnyih: rekomendatsii / A.N. Lazarevich, A.P. Lesnov; FGBNU Krasnoyarskiy NIIZh. - Krasnoyarsk, 2016. - 90 s.

15. Jane Wamatu Nutritive value of field pea (Pisum sativum L.) straw as influenced by variety, season, botanical fractions and urea pretreatment / Jane Wamatu, Ashraf Alkhtib, Dawit Abate, Seid Ahmed Kemal, Barbara Rischkowsky // Animal Feed Science and Technology. - Volume 225. - 2017. - P. 54-61. ISSN 0377-8401.

16. Pablo Gregorini Screening for diets that reduce urinary nitrogen excretion and methane emissions while maintaining or increasing production by dairy cows / Pablo Gregorini, Pierre C. Beukes, Dawn Dalley, Alvaro J. Romera // Science of the Total Environment. - 2016. P.- 32-41.

17. Biohimicheskie markeryi vospaleniya tkaney rotovoy polosti: metod. rekomendatsii / A.P. Levitskiy, O.V. Denga, O.A. Makarenko [i dr.].- Odessa, 2010. - 16 s.

18. Fermentativnyiy metod opredeleniya disbioza polosti rta dlya skrininga pro- i prebiotikov: metod. rekomendatsii / A. P. Levitskiy, O. A. Makarenko, I.A. Selivanskaya [i dr.]. - K.: GFTs, 2007. - 26 s.

Надійшла 07.05.2018. До друку 17.05.2018

Адреса для переписки

вул. Канатна, 112, м. Одеса, 65039

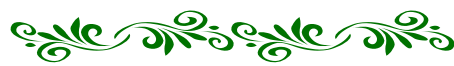

\section{ОСОБЛИВОСТІ КОНСТРУКЦІЇ І ЗАСТОСУВАННЯ ФОТОЕЛЕКТРОННОГО ОБЛАДНАННЯ АЛЯ РОЗДІ- ЛЕННЯ ЗЕРНА I ЗЕРНОПРОДУКТІВ НА ФРАКЦІЇ ЗА ОЗНАКОЮ КОЛЬОРУ}

\footnotetext{
Анотація

Фотоелектронне сепарування застосовують для сортування різноманітних сипких продуктів, у тому числі - зерна і деяких продуктів його переробки.

Фотоелектронні сепаратори використовують для очищення зерна від важковідділюваних домішок, які досить складно або навіть неможливо відокремити з допомогою звичайних зерноочисних сепараторів. Окрім того, їх застосування доиільне для розділення на фракиії основних продуктів лущення зерна круп'яних культур.

Фотоелектронне, або оптичне сепарування базується на ідентифікації частинок сипких продуктів як за ознакою кольору, так і їх форми і текстури. Для иього використовують оптичні камери. Електронні блоки обробки отриманої графічної інформачії передають ї̈ в пневматичні пристрої ежекторного типу для виведення домішок із основного потоку продукту. Оптичні датчики і повітряні ежектори функиіонують у безконтактному режимі, що повністю узгоджуються з вимогами гігієнічності харчових технологій. До того ж вони є швидкодіючими, щьо забезпечує високу продуктивність сепарування. Ефективність вилучення домішок сягає 80...99,99\%. Довговічність фотоелектронних сепараторів характеризують числом цииклів $N_{u}$ спрацювання пневматичних клапанів ежекторів. Більшість фірм гарантує $N_{u} \geq 50$ млн циилів.
} 